\title{
On the Continuity of Old Saami Religion
}

\author{
By ROLF KJELLSTRÖM
}

In the earlier permanent Saami exhibition at the Nordic Museum in Stockholm it was possible to read, "Drum magic was officially eradicated with the Christianisation of the Lapps in the 17th and 18th centuries, but drums were used secretly well into the 19th century". This contemporary view of the drum and other phenomena connected with the Lapps' traditional religion seems to accord rather well with the opinions of other scholars. Furthermore, it does not seem as if people in general considered that this period was any longer in this respect. Israel Ruong, for example, suggests nothing about such religious practices in his publications but points out - obviously as some kind of late example-how relics of a belief in shamans were to be found as late as the middle of the 19th century in Finnmark (Ruong 1982, 58).

Among religious historians it is Hans Mebius who goes farthest forward in time; in his valuable essay Sjiele he is fully aware that sacrificial traditions, for example, continued to live on long after the arrival of missionaries and other such activities among the Saamis. Mebius comes to this conclusion partly on the basis of actual information found in sources that he had consulted and partly as a result of the detailed and wellinformed knowledge shown by the informants in the 19th-century sources (Mebius 1972, 100). The question now is whether such sacrificing customs and similar traditions were current even later than what research has suggested and if so, how late in time. I wish to cast some light on this problem by presenting a number of examples taken in part from the literature about the Saamis, in part from personal communications from other scholars and in part from my own interviews observations in the field.

If we begin from the north, I should like to mention an example from the parish of Karesuando referred to by Ossian Elgström and dating back to the beginning of the 20th century. He reports how a man was about to sacrifice a reindeer after having tried in vain to obtain help from the Christian God. The background to this was that the man had earlier lost two sons and the third was now very ill. In a situation like this the man was, so to speak, willing to try yet another possibility in a very difficult situation (Elgström 1922, 249). The example is probably not unique.

One of Manker's informants from the parish of Jukkasjärvi said that 
sacrifices were made in the early 19 th century but examples are also given from as late as the 1910's. A fishing Lapp from Kortolahti on Lake Torne offered up money at a sacrificial site at Vuoitaskallo. This sacrifice was made during a wolf hunt which had hitherto been unsuccessful. However, after the sacrifice the hunters were more lucky (Manker $1957 a$, $92 \mathrm{f}$.).

In Demant-Hatt's opinion it was also likely that the occasional Saami continued to make offerings at that time-around 1907-probably when passing the old sacrifical sites in the course of nomadic migrations or in connection with hunting or fishing trips. Among the Saamis there still existed the view that good fortune forsook certain families after they had ceased to make offerings to the gods (NM Demant-Hatt 1907-1913).

According to my informant it happened that a certain measure of respect was accorded to the sacrifical sites in the Kaitum valley in the parish of Gällivare even as late as the 1950's (NM Kjellström 1984).

We continue south to the parish of Jokkmokk. In 1907 there was a report in the newspaper Norrbottenskuriren that at Jaurekaska a Saami had tried to persuade the spirit of the local rapids to give him good fishing. To do this the man had laid out an old fishing net and a birchwood bowl, in which he had placed a few whitefish wrapped in birchbark. The newspaper noted that "belief in the old gods is persistent in the wilds of Lapland". (Norrbottenskuriren 1903, 26.8).

Much later, in 1945, Manker tried to visit a well-known but unlisted sacrificial site at Tjakkeli but it proved extremely difficult-even impossible-for Manker to get any Saami to show him the place. The nearest that Manker could get was a vague indication of where the place was situated. When he finally succeeded in reaching the site, a very peculiar thing happened-six adders appeared-in an area high above the limit of coniferous forest where adders had never been seen before.

It may be added that the Saami who had indicated the sacrificial site to Manker, Petrus Gruvvisare, later had such pain in one leg that he was forced to go to Stockholm for radium treatment. He claimed that the pain in his leg had begun at the very spot where he had told Manker about the offering site (Manker 1957 a, 189; Manker 1957 b, 108-126).

When I spoke to Gruvvisare much later, there was no mistaking how strong an influence the episode with the adders at the offering site had had on him. However, his leg got better and he is still alive (NM Kjellström 1975).

In the course of the intensive inventory work that we have been conducting at the Nordic Museum for the last decade or so quite a large number of cultural relics related to Saami cult practices have been found. In an area about $10 \mathrm{sq}$. $\mathrm{km}$ along the frontier between the Sarek and Padjelanta 
national parks in the parish of Jokkmokk a total of 31 sites have been found which have cult associations. They comprise collections of bones and horns that have been collected in a systematic fashion and deposited in a sheltered place. For example, I found a place with a whole reindeer that had been sacrificed. It is obvious that such material has a lot to offer the scholar of comparative religion and should therefore be the object of further study. As for the age of the bones and horns, it is difficult to judge but we have guessed that most of them were deposited there between 1850 and 1950. If this guess is correct, then it means that well-known sacrifice traditions must have continued right up to quite recent times (Kjellström 1983; Kjellström 1985).

Mention may also be made of the fact that in 1932 a ritual fortune-telling drum was found in a cave in the study area (Manker $1957 \mathrm{a}, 192 \mathrm{f}$.) and close by the same area another drum was found only a few years ago. It is rumoured that there are still such drums-albeit not in use-in the Jokkmokk mountains (NM Kjellström 1978).

There are also reports that a kind of shaman lived in the parts around Peurare at the turn of the century. He is said to have had a special spring where he made offerings (Andersson, Hans-pers. comm. 1985).

Travelling farther south we come to the parish of Arjeplog, where I have made notes in the course of my own fieldwork. However, I have also been in a position to study the information collected so admirably by Dr Einar Wallquist. I should like to take the opportunity to thank him for all the help that he gave on this occasion-as on so many others.

It is quite clear that in the 19 th century at least that sacrificing was widely practised in these parts, but there are also several examples of such practices during the present century, as I shall briefly relate.

A relative of one of my informants had, according to reliable information, a ritual drum which he used to tell fortunes. However, he got the idea that it was not a good thing to keep the drum at home so it was hidden elsewhere. This man died in 1958. With his death the drum was lost-or rather it could no longer be found. As a result another member of the family tried to make a new drum. My informant was himself a witness to how the frame of the drum was made. How, or indeed, whether it came to be used I do not know (NM Kjellström 1984).

The last known offering of a whole reindeer, a large white buck, was made in the Saami village at the beginning of this century. But offerings also occurred even later than this according to my informant. The last was probably made in a gorge at Vuornatj in Bårrok (NM Kjellström 1984).

In this connection it is worth remembering what Margareta Bengtsson told Demant-Hatt concerning the Piteå Lapp area: "It was the custom in 
olden days to sacrifice one reindeer a year, in late summer [...] to the earth. This custom was called Boaldon vieron. The reindeer was first adorned and then slaughtered with a knife and thereafter burned, after which its bones were buried" (Demant-Hatt 1928, 48).

Einar Wallquist gives the following example. "A settled Lapp, born in 1887 and long since dead, told me that when he was a boy in the 1890's, he had played on a ritual drum owned by a Lapp relative of his in the valley behind Ramain. His father had been very angry that he had touched the drum. He described it; it resembled an ordinary drum. A crown forester, born in 1876, had come to hear about the drum and managed to get hold of it. He took it with him in his rucksack, skied to Västerfjäll where he was to spend the night but when the Lapps who lived there heard what he had with him, they forbade him to bring it into the camp. He was forced to hang it in a birch tree outside the fence for the night. In order to calm the Lapps. This was told me by the forester's daughter, who was born in 1911. She remembers it, she saw it in her early childhood, around 1920. It was not like the older drums, oval and low, but cylindrical in form with figures painted on the skin stretched over one end. Manker mentions that such drums existed up to a very late date" (Wallquist, Einar-pers. comm. 1984).

The next example is from Lövnäs. "A peasant woman from Lövnäs at Arjeplog, born in 1924, told me that on the farm they had frequent contacts with the Lapps from the Lapp village of Semisjaure-Njarg when they passed by on their travels. A Lapp woman, born in 1884, had developed a great trust in the peasant woman. The Lapp woman caught cancer; she got worse and worse. Some time in the 1940's she came to the peasant woman and asked to speak to her. She expressed great fear and spiritual anxiety about the end that would soon face her. She was a Christian but she and her husband, born in 1899, had nonetheless made offerings to the old Lapp gods every year in a cave up on Barturte fell. Now she was worried that her sins would not be forgiven on account of this heathen practice and told the peasant woman about it. The peasant woman then told me everything when the woman and her husband had died. I succeeded in persuading a Lapp who had a sensible attitude towards the old rites to try and find the grotto again but found nothing there. He thought that other Lapps had got wind of what he was about to do and had borne everything away" (Wallquist, Einar-pers. comm. 1984).

Among the Karesuando Lapps who arrived in the early 1920's there was a woman who went to Roggejaure and made sacrifices there. It was also rumoured that they brought some ritual drums with them, not the very religious Laestadians, however, who settled mainly in the area of the Pite river. The Karesuando Lapps on Svaipa fell and farther south of the parish 
were only exceptionally orthodox Laestadians. "A man born in 1931," says Wallquist, "who had often been with the Lapps in the Svaipa area once saw a ritual drum in a barn in the 1960's; he did not remember who it belonged to. He said that the drum was not like the one in Silvermuseet; instead it was shaped like a bowl, a large wooden bowl, in other words a northern drum that the Karesuando Lapps had probably brought with them on their wanderings south. I asked a number of Lapps in the area if there might possibly still be such a drum there. They were doubtful and said that the older generation had believed in them and used them but the younger generation did not approve of such rites and had thrown their drums in a barn around the 50's and 60's. There they had lain and people still remembered them. The barns had gradually rotted away and contained only rubbish so they said. The barns had been burnt down, contents and everything. They therefore did not think that there were any drums left but promised to have a look. However, they were still there in the 1950's and still used by the old people, that much is known"' (Wallquist, Einar-pers. comm. 1984).

One of Einar Wallquist's informants is a Saami born in 1931 whose forefathers came from Karesuando. He told Wallquist that he is still in the habit of laying out a few coins when he passes the well-known seite at Svaipavalle. He has his cabin nearby at Tjolmejaure and beside it there is a large light seite to which he still makes offerings. Moreover, he also has a small seite inside his cabin to which he often directs wishes for good fishing. There can be no doubt, says Wallquist, that the man really believes in his gods. This information has been confirmed by others. "A man who often visits Svaipa fell once saw this Lapp at a distance without the Lapp noticing him. He was standing throwing ashes over his shoulder in different directions and was talking to himself. However, he seemed to be in some kind of a trance and 'far away'. He has heard that others have also seen the Lapp in a similar state of psychic influence" (Wallquist, Einar-pers. comm. 1984).

The detail about laying out coins occurs in many parts of Lapland but Wallquist contributes a further example encountered at Arjepolog. "A settled person of Lappish origin, born in 1925, his wife is a true Lapp, lives in a village of the forest Lapps. He knew of a sacrificial site on Lake Seite near the Lapp village of Maskaur; the site is mentioned by Ernst Manker. The seite there is said to have been thrown into the lake. In quite deep water not far from the shore the man found a stone resembling a bird of a species not found in the neighbourhood. It may very well have been the lost seite for an old Lappish legend says that a bird flew to the Tarra valley, was turned into stone but nevertheless continued to sing. He took the seite 
home with him and put it in a barn. One day he caught a lot of fish and a neighbour from the Lapp village asked how that had happened. He replied that it was thanks to the seite that he had found. One day the neighbour came and asked to see the seite. The man told him that he could go out to the barn where it stood. When the owner of the seite went out to the barn some days later he saw that his neighbour had placed some 1-crown coins on the seite, in other words, made an offering" (Wallquist, Einar-pers. comm. 1984).

Even if the old beliefs have been abandoned in most cases, people still very often respect the places held sacred by earlier generations. An elderly man once told me, for example, that when he passes such a place, he always stops and thinks for a moment of what it meant for earlier generations. He feels an awe and peace which reminds him of devotion. He never allows his dog to urinate against the seite (Wallquist, Einar-pers. comm. 1984).

There are of course numerous examples of superstition of different kinds from the parish of Arjeplog but we shall not go into them here.

Let us move on from Arjeplog to the parish of Tärna. Here there are notes made by O. P. Pettersson in 1905 concerning Kristoffer Sjulsson.

Collections of bones 'järtesie' from the animals and birds consumed by the Lapps were a common occurrence in Sjulsson's youth about the middle of the 19th century (Pettersson 1979, 60f.). Such bone remains are still quite common in many parts of Sjulsson's home tract near Abelvattnet even though the realisation of their import had already disappeared by the beginning of the century according to Kristoffer Sjulsson (NM Kjellström 1979-84; Pettersson 1979, 63).

Another type of offering was vero; such places were marked by an arrangement of stones on the ground where a reindeer buck had been buried in a cairn of stones with only the tip of one horn visible above the ground. In his youth Kristoffer Sjulsson saw many such sites but gradually the horns rotted away and the places became increasingly difficult to identify. It has been possible to locate several such sites, however, in the area (Pettersson 1979, 63 f.; NM Kjellström 1977-84).

A further phenomenon was sacrificial stones, verogerke, and about the middle of the 19th century small offerings of little importance were still made to such stones. Such offerings might consist of brass rings, glass beads, brass wire, etc. At that time people still believed in, or rather feared, the power of such stones; they thought that the stone had the power to harm them (Pettersson 1979, 64).

At Vilhelmina an informant told Manker that it was still the custom to make offerings during the latter half of last century. The informant's father, 
the well-known lynx and wolf hunter Jon Andersen Neiner, is said to have been the first to break the tradition of making offerings to the stone at Offerskalet; that was in about 1860 . But it was the custom to make offerings at this site when travelling by during the spring and autumn migrations (Manker $1957 a, 88,93$ ).

Torkel Tomasson, himself a Saami, has provided valuable notes on the topic. For example, he reports an example from the parish of Vilhelmina in 1917 concerning the first time of the year that the reindeer were milked. His informant was an 80-year-old woman; "It was early summer one year when the informant and his wife drove the herd of reindeer into the pen to milk them for the first time. An old Lapp woman, who was maid to the informant, said, "See to it that you offer a little to the spirit now that you are about to milk the reindeer for the first time this year.' But the informant took no notice. Soon afterwards, however, a buck reindeer went lame and the informant began to wonder whether perhaps her failure to give the 'spirit' something had anything to do with it" (ULMA Thomasson 1917, 58).

We now travel even farther south-to the parish of Frostviken, where Demant-Hatt made notes in 1910's. One of Demant-Hatt's informants had an old relative who had bought a silver harness for his reindeer and then buried it alive with only its head above the ground. The place was flat and even and lay near a stream, probably not far from Ankarrede. Another of the man's relatives had happened to see the reindeer while it still lived and had thought to kill it so that it would not have to continue to suffer but had not dared to do so. The reindeer grave had been dug with a reindeer horn.

There were several other such places in these mountain according to a report dated 1913. One was situated on the eastern side of Bastu fell. The reindeer sacrificed there had also been decorated with ornaments of silver but when the informant visited the site, some of the silver leaves had fallen to the ground.

In another case a year-old reindeer had been adorned and then sacrificed. These offerings of reindeer still took place about the turn of the century according to report. Later, it sometimes happened that, instead of reindeer, something else more mundane such as tobacco or snuff were left at the site (Demant-Hatt 1928, $49 \mathrm{f}$.).

I wish to quote the following example from the parish of Undersåker in central Jämtland. In 1972 I was contacted by a local inhabitant of Ottsjö who told me that some years earlier some youths had found a wooden object about one metre in length that had been carved to some extent but resembled nothing that they recognised. After this telephone call I took the night train to Jämtland and reached the place where the find had been made the next day. It lay by a steep cliff about $900 \mathrm{~m}$ above sea level; there was 
also a chasm and the whole place was covered with a large "roof". This was where the seite was hidden. In the middle of this semi-ravine there was a hillock on a plateau which had, in all probability, been artificially constructed. This peculiar site accords rather well with earlier finds of wooden seites and other cult locations.

The wooden object proved to have two parts-we might call them arms - and was reminiscent of the wooden idol from Överstjuktan. Comparisons of the wooden artefact from Ottfjället with other wooden idols showed that the one from Ottfjället was more stylised, more like a carving of Christ.

The artefact was sent in for dating and the answer was most unexpected; it proved to be 65 years old. Even if this figure must be treated with great reservation, it shows that this wooden idol was of relatively late date.

Who had used the site? Suspicion soon fell on a Saami in the region called Lill-Mårten. He was mentioned in a book by Torsten Boberg, who was familiar with the fells. He had called a chapter about Mårten "Christian heathen", indicating that Mårten had one foot in Christianity and the other in old Saami beliefs. It was a well-known fact that this Lapp had a statue of a god and a sacrificial site somewhere in the mountains; Boberg tried to find out where the whole of his life. He writes, "I must admit that my innermost desire [...] was to find the old Lapp god and the offering sacrificial site". When during the final years of Mårten's life, Boberg plied him with questions about the wooden idol, Mårten would answer, "You shall know nothing. You are too young and to stupid, and it's too important a matter." The man's attitude towards the old religion of the Lapps can be detected in this answer (Boberg 1946).

To cut a long story short, it may be noted that Mårten had lived only about $700 \mathrm{~m}$ from where the idol was found, and it was obviously his sacrificial site that the youths had uncovered. Mårten Thomasson was born in 1849 and died in 1924 (Kjellström 1975).

According to Demant-Hatt the ritual drum would seem to have disappeared from the southern parts of Lapland later than from the more northerly parts. People still remembered such drums quite well when Demant-Hatt visited Lapland in about 1910 and were occasionally still preserved at the end of the 19th century. One of Demant-Hatt's informants at Tännäs parish, for example, could remember his grandmother having a drum with her when she moved from Frostviken to Härjedalen. The informant was then ten years old.

Another man had been forced to hide his drum in a crevice on the mountainside after his children started to go to school and had come home with new ideas about such things (Demant-Hatt 1928, $53 \mathrm{ff}$.). 


\section{Summary}

In my paper I have given some examples of a few elements that formed part of traditional Saami religion. However, my report is by no means the result of a full and careful study. Rather, it is a collection of very sporadic impressions and observations. Nor has it been possible to determine the degree of intensity or frequency with which this religion was practised. Nor, moreover, has any comparison been made with earlier epochs concerning the form that these elements took.

What we can note is that certain traditional elements of Saami religion-at least in a few individual cases and in part perhaps in somewhat changed form-have continued to exist right up to quite recent times and, indeed, still live on, above all in the southerly parts of the region inhabited by the Lapps.

In cases where the practice of making offerings ceased, the people still continued to show respect and veneration for the religious sites and could even experience something of the force emanating from them. They therefore felt a need to shield themselves from these forces and consequently followed the traditional practices. Their respect, however, still persisted.

Early Saami religion and Christianity undoubtedly continued to exist side by side. It is possible that in their traditional livelihoods and even in life in general they resorted to their former well-tried religion, especially when all else failed.

The purpose of my paper has been to draw attention to the fact that old Saami religion is not entirely extinct. Instead, there still exist elements worth taking into account and trying to discover more about.

In the course of submitting this manuscript I have learned that the report from the symposium will be dedicated to Carl Martin Edsman. I note this with great pleasure and feel very grateful for the opportunity to contribute.

I remember at the same time how Carl Martin Edsman, in a highly complicated scholarly question many years ago, came into a field where I for once happened to know the literature well. The scholarly analysis which Carl Martin Edsman presented on that occasion was a superb achievement and so impressive that he became my scholarly "idol"-which he has remained. 


\section{Bibliography}

UNPUBLISHED SOURCES AND LITERATURE

Stockholm

NM Nordiska museet

Lapska avdelningen

Demant-Hatt, E. 1907-1913. Anteckningar från lappmarkerna. LA 1100.

Kjellström, R. 1975-84. Fältanteckningar från lappmarkerna.

Wallquist, E. 1984. Brev rörande lapparnas offer och övertro.

Uppsala

ULMA Dialekt- och folkminnesarkivet i Uppsala

Tomasson, T. 1917. Några sägner, seder och bruk upptecknade efter lapparna i Åsele och Lycksele lappmark samt Härjedalen. 385.

\section{PUBLISHED SOURCES AND LITERATURE}

Boberg, T. 1946. Ränna på björn och andra fjällskildringar. Uppsala.

Demant-Hatt, E. 1928. Offerforestillinger og erindringer om troldtrommen hos nulevende lapper. Festskrift til rektor J. Qvigstad. (Troms $\emptyset$ museums skrifter 2.) Oslo.

Elgström, O. 1922. Karesuandolapparna. Stockholm.

Kjellström, R. 1975. Träguden från Ottfjället. Fataburen.

- 1983. Lappmarksmikroskop. Stockholm.

- 1985. Piles of bones, cult-places or something else? Arv.

Manker, E. 1957 a. Lapparnas heliga ställen. (Acta Lapponica 13.) Uppsala.

- 1957 b. Bortom fjällen. Stockholm.

Mebius, H. 1972. Sjiele. (Skrifter utg. av Religionshistoriska institutionen i Uppsala, Hum. fak., 9.) Uppsala.

Norrbottenskuriren. 1903. 26.8. Nr 133.

Pettersson, O. P. 1979. Kristoffer Sjulssons minnen. [Ed. by] L. Bäckman \& R. Kjellström. (Acta Lapponica 20.) Stockholm.

Ruong, I. 1982. Samerna $i$ historien och nutiden. Stockholm. 